\title{
Polycyclic aromatic hydrocarbons and risk elements in honey from the South Moravian region (Czech Republic)
}

\author{
Petra Batelková ${ }^{1}$ Ivana Borkovcová1, Olga Čelechovská ${ }^{2}$ Lenka Vorlová ${ }^{1}$, \\ Klára Bartáková ${ }^{1}$ \\ ${ }^{1}$ Department of Milk Hygiene and Technology, ${ }^{2}$ Department of Biochemistry, Chemistry and Biophysics, \\ Faculty of Veterinary Hygiene and Ecology, University of Veterinary and Pharmaceutical Sciences Brno, \\ Czech Republic
}

Received August 31, 2011

Accepted April 11, 2012

\begin{abstract}
The aim of this study was to determine the actual content of some exogenous contaminants in the honey from the South Moravian region of the Czech Republic. The content of polycyclic aromatic hydrocarbons (PAHs) and risk elements (Mercury - Hg, Cadmium - Cd, Lead - Pb, and Arsenic - As) in multifloral blossom and honey dew samples of honey were determined by high-performance liquid chromatography and atomic absorption spectroscopy methods. The samples were collected form beekeepers and from retail stores located in South Moravia in the Czech Republic. Concentrations of individual PAHs in honey samples ranged between $0.02 \mu \mathrm{g} \cdot \mathrm{kg}^{-1}-1.93 \mu \mathrm{g} \cdot \mathrm{kg}^{-1}$. The limit of benzo[a] pyrene for infant formula $\left(1.0 \mu \mathrm{g} \cdot \mathrm{kg}^{-1}\right)$ was not exceeded and fluoranthene was not quantified in any of the samples. Concentrations of $\mathrm{Hg}, \mathrm{Cd}$, and $\mathrm{Pb}$ were in the range of $3.24 \mu \mathrm{g} \cdot \mathrm{kg}^{-1}-11.31 \mu \mathrm{g} \cdot \mathrm{kg}^{-1}$, $0.95 \mu \mathrm{g} \cdot \mathrm{kg}^{-1}-32.35 \mu \mathrm{g} \cdot \mathrm{kg}^{-1}$, and $22.80 \mu \mathrm{g} \cdot \mathrm{kg}^{-1}-177.85 \mu \mathrm{g} \cdot \mathrm{kg}^{-1}$, respectively. Concentration of As exceeded the detection limit only in three samples, ranging from $3.51 \mu \mathrm{g}^{\mathrm{kg}} \mathrm{kg}^{-1}$ to $4.35 \mu \mathrm{g} \cdot \mathrm{kg}^{-1}$. Acceptable limits for trace elements in infant formula were met. Results of this study complete present knowledge of the contaminant content in Czech honey and confirmed high quality and safety of honey from the South Moravian region.
\end{abstract}

Persistent organic pollutants, toxic elements, HPLC, atomic absorption spectroscopy

Honey contains a number of nutritionally valuable compounds and is appreciated for its healing and prophylactic properties. These result from its composition and are reflected by physicochemical and chemical indicators (Lachman et al. 2010). According to some authors, honey is considered an environmental marker due to its ability to contain harmful substances coming from polluted environment and beekeeping practices, e.g. trace elements (Conti and Botre 2001), pesticides (Blasco et al. 2003), antibiotic residues (Hammel et al. 2008), and polycyclic aromatic hydrocarbons (PAHs) (Dobrinas et al. 2008). On the other hand, honeybees use their own detoxification mechanisms to decrease the content of harmful substances (Ferreira et al. 2010; Niu et al. 2011). The PAHs belong to the family of persistent organic pollutants with properties negatively impacting the human organism such as carcinogenicity, mutagenicity, etc. (Ramesh et al. 2004). Inhaled air and foodstuffs represent the main exposure source of PAHs for most of the population (Alexander et al. 2008). Data on the PAHs content in honey are very rare, nevertheless, some authors reported high concentrations of PAHs in honey (Dobrinas et al. 2008). Trace concentration of metals in honey and their high variability are dependent very strongly on the botanical and geographical origin, and less on the climatic and seasonal criteria (Celechovská and Vorlová 2001). Remarkably elevated values of trace elements in honey were reported in samples from industrial and otherwise polluted areas (Bogdanov et al. 2007). The influence of environmental anthropogenic contaminations on the risk element content in honey is still discussed (Claudianos et al. 2006; Fredes and Monten egro 2006; Tuzen et al. 2006) because of evident low metal bioaccumulation (Conti and Botre 2001). On the other hand, according to previous studies the presence of toxic metals in honey is

Address for correspondence:

Ing. Petra Batelková

Department of Milk Hygiene and Technology

Faculty of Veterinary Hygiene and Ecology

University of Veterinary and Pharmaceutical Sciences Brno

Palackého tř. 1/3, 61242 Brno, Czech Republic

Phone: +420777 887933

Fax: +420541562711

E-mail: batelkova@email.cz

http://actavet.vfu.cz/ 
significantly influenced by the environmental pollution (Toporčák et al. 1992; Pisany et al. 2008).

The aim of our study was to determine the actual content of exogenous contaminants, i.e. PAHs and toxic elements $(\mathrm{Hg}, \mathrm{Cd}, \mathrm{Pb}$, and $\mathrm{As})$ in honey from the South Moravian region of the Czech Republic, to compare our results with known data obtained from previous studies, and to confirm the quality and safety of the honey tested.

\section{Materials and Methods}

Sample characterization

Samples of honey were obtained from beekeepers located around the city of Brno (honey no. 1-10) and from Brno retail stores (honey no. 11-20). The country of origin of all honey samples was declared as the Czech Republic. Samples no. 1 and 2 were honey dew honeys and the remaining samples were multifloral blossom honeys.

PAHs analysis

We monitored the content of 15 PAHs pollutants in honey according to the US EPA (EPA/630/R-98/002, 1986), namely acenaphtene (Ace), anthracene (Ant), benzo[a] anthracene (BaA), benzo[a]pyrene $(\mathrm{BaP})$, benzo $[g, h, i]$ perylen (BghiP), benzo[b]fluoranthen $(\mathrm{BbF})$, benzo $[k]$-fluoranthene $(\mathrm{BkF})$, chrysene $(\mathrm{Chr})$, dibenzo $[a, h]$ anthracene (DahA), fluorene (Fl), fluoranthene $(\mathrm{Fu})$, indeno[1,2,3-c,d] pyrene (IPy), naphthalene (Na), phenanthrene (Phe), and pyrene (Py). The honey sample $(10 \mathrm{~g})$ was mixed with anhydrous sodium sulphate, and $40 \mathrm{ml}$ of dichloromethane were added and mixture was extracted by means of ultrasonic bath and Ultra Turrax. After filtration the solvent was evaporated to dryness (Büchi, Flawil, Switzerland), redissolved in $1 \mathrm{ml}$ of acetonitrile, filtered $(0.45 \mu \mathrm{m}$ nylon membrane filter) and analysed by HPLC - Waters 2695 Alliance chromatographic system equipped with Empower 2 software, and the Waters 2475 Fluorescence Detector (Waters, Milford, USA) using an excitation and emission wavelength program. The PAH C18 column $(250 \mathrm{~mm} \times$ $4.6 \mathrm{~mm}$ I.D. $5 \mu \mathrm{m}$ - Waters, Milford, USA) was used. Column temperature was $30^{\circ} \mathrm{C}$, mobile phase A (water) and $\mathrm{B}$ (acetonitrile). The gradient elution was programmed as follows: $50 \% \mathrm{~B}(0-5 \mathrm{~min}), 50 \% \mathrm{~B}$ to $100 \% \mathrm{~B}$ linearly (5-20 min), 100\% B (20-28 min), 100\% B to 50\% B linearly (28-32 min). The flow rate was set at $1.4 \mathrm{ml} \cdot \mathrm{min}^{-1}$. Quantification was carried out by the external standard method.

Risk element analysis

Risk elements $\mathrm{Cd}$ and $\mathrm{Pb}$ were determined by electrothermal atomization HR-CS AAS (High Resolution Continuum Source Atomic Absorption Spectrometry) on the ContrAA 700 apparatus (Analytik, Jena, Germany) after mineralization of the sample with concentrated nitric acid and hydrogen peroxide in a laboratory autoclave with microwave heating (Ethos Sel, Milestone, Sorisole, Italy). For determination of As, the sample (after

Table 1. Additional information about the experimental conditions of risk elements analysis in honey.

\begin{tabular}{lcccc}
\hline Element & $\lambda(\mathrm{nm})$ & Atomization $\left({ }^{\circ} \mathrm{C}\right)$ & Modificator & $\begin{array}{c}\text { Calibration } \\
\left(\mu \mathrm{g} \cdot l^{-1}\right)\end{array}$ \\
\hline $\mathrm{Cd}$ & 228.8018 & 1500 & $\mathrm{Pd}\left(\mathrm{NO}_{3}\right)_{2}$ & $0.5-4.0$ \\
$\mathrm{~Pb}$ & 283.3060 & 1900 & $\mathrm{Pd}\left(\mathrm{NO}_{3}\right)_{2}$ & $5.0-40.0$ \\
$\mathrm{As}$ & 193.6960 & 2200 & $\mathrm{Ir}$ & $0.25-2.0$ \\
\hline
\end{tabular}
mineralization in autoclave) was ashed with the addition of magnesium nitrate in a muffle oven at $450^{\circ} \mathrm{C}$. The ash was dissolved in hydrochloric acid and $\mathrm{As}^{\mathrm{V}}$ was reduced to $\mathrm{As}^{\mathrm{III}}$. Arsenic was determined by hydride technique in graphite atomizer, HS 60 (Analytik). The apparatus was set to the conditions recommended by the producer and the temperature program was optimized for the individual elements (see Table 1). The measurement of $\mathrm{Hg}$ was done by HR-CS AAS on an Advanced Mercury Analyzer AMA - 254 (ALTEC, Dvůr Králové nad Labem, Czech Republic).

Statistics

Basic statistical characteristics (mean, standard deviation, minimum, maximum) for the exogenous elements were calculated using Microsoft Excel 2003. Statistical assessment of the data was carried out using the statistical and graphic software STAT Plus (Matoušková et al. 1992).

\section{Results}

\section{Polycyclic aromatic hydrocarbons}

Limit of detection (LOD) and limit of quantification (LOQ) ranged from $0.01 \mu \mathrm{g} \cdot \mathrm{kg}^{-1}$ to $0.21 \mu \mathrm{g} \cdot \mathrm{kg}^{-1}$ and from $0.02 \mu \mathrm{g} \cdot \mathrm{kg}^{-1}$ to $0.68 \mu \mathrm{g} \cdot \mathrm{kg}^{-1}$, respectively. Recoveries of PAHs ranged from $60.5 \%$ (Fl) to $103.2 \%$ (Ace). Repeatability expressed as relative standard deviation (RSD) of 12 parallel measurements was no higher than $3.0 \%$. The average concentrations of individual 
PAHs in samples from beekeepers and in samples from retail ranged from $0.02 \mu \mathrm{g} \cdot \mathrm{kg}^{-1}$ to $1.60 \mu \mathrm{g} \cdot \mathrm{kg}^{-1}$ and from $0.04 \mu \mathrm{g} \cdot \mathrm{kg}^{-1}$ to $1.93 \mu \mathrm{g} \cdot \mathrm{kg}^{-1}$, respectively. Maximum value of $\mathrm{BaP}$ was $0.83 \mu \mathrm{g} \cdot \mathrm{kg}^{-1}$ (samples from retail) and $0.81 \mu \mathrm{g} \cdot \mathrm{kg}^{-1}$ (samples from beekeepers) (Table 2, 3).

Table 2. Concentrations of polycyclic aromatic hydrocarbons $\left(\mu \mathrm{g} \cdot \mathrm{kg}^{-1}\right)$ in honey samples collected from beekeepers.

\begin{tabular}{|c|c|c|c|c|c|c|c|c|c|c|c|}
\hline \multirow{2}{*}{ PAHs } & \multicolumn{10}{|c|}{ Honey samples } & \multirow{2}{*}{ Range } \\
\hline & 1 & 2 & 3 & 4 & 5 & 6 & 7 & 8 & 9 & 10 & \\
\hline $\mathrm{Na}$ & $<\mathrm{LOQ}$ & $<\mathrm{LOQ}$ & $<\mathrm{LOQ}$ & $<\mathrm{LOQ}$ & $<\mathrm{LOQ}$ & $<\mathrm{LOQ}$ & $<\mathrm{LOQ}$ & $<\mathrm{LOQ}$ & $<\mathrm{LOQ}$ & $<\mathrm{LOQ}$ & $<$ LOQ \\
\hline Ace & $<\mathrm{LOQ}$ & $<\mathrm{LOQ}$ & $<\mathrm{LOQ}$ & 1.12 & $<\mathrm{LOQ}$ & $<\mathrm{LOQ}$ & $<\mathrm{LOQ}$ & $<\mathrm{LOQ}$ & $<\mathrm{LOQ}$ & $<\mathrm{LOQ}$ & $<\mathrm{LOQ}-1.12$ \\
\hline $\mathrm{Fl}$ & 0.58 & 1.30 & 0.81 & 1.60 & $<\mathrm{LOQ}$ & 1.22 & 0.82 & $<\mathrm{LOQ}$ & 0.65 & 1.35 & $<\mathrm{LOQ}-1.60$ \\
\hline Phe & 0.71 & 0.83 & 0.67 & 0.71 & 1.26 & 0.72 & 0.84 & 0.08 & 1.58 & 0.87 & $0.08-1.58$ \\
\hline Ant & 0.71 & 0.73 & 0.72 & 0.73 & 0.74 & 0.72 & 0.72 & 0.04 & 0.74 & 0.75 & $0.04-0.75$ \\
\hline $\mathrm{Fu}$ & $<\mathrm{LOQ}$ & $<\mathrm{LOQ}$ & $<\mathrm{LOQ}$ & $<$ LOQ & $<\mathrm{LOQ}$ & $<\mathrm{LOQ}$ & $<\mathrm{LOQ}$ & $<\mathrm{LOQ}$ & $<\mathrm{LOQ}$ & $<\mathrm{LOQ}$ & $<$ LOQ \\
\hline Py & 0.44 & 0.49 & 0.47 & 0.45 & 0.56 & 0.51 & 0.47 & $<\mathrm{LOQ}$ & 0.58 & 0.53 & $<\mathrm{LOQ}-0.58$ \\
\hline $\mathrm{BaA}$ & 1.39 & 1.41 & 1.39 & 1.40 & 1.40 & 1.40 & 1.39 & 0.04 & 1.41 & 1.41 & $0.04-1.41$ \\
\hline $\mathrm{Chr}$ & 1.22 & 1.28 & 1.24 & 1.25 & 1.25 & 1.22 & 1.23 & 0.05 & 1.31 & 1.26 & $0.05-1.31$ \\
\hline $\mathrm{BbF}$ & 0.45 & 0.46 & 0.42 & 0.02 & 0.45 & 0.41 & 0.44 & $<\mathrm{LOQ}$ & 0.03 & 0.92 & $<\mathrm{LOQ}-0.92$ \\
\hline $\mathrm{BkF}$ & 0.82 & 0.82 & 0.82 & 0.82 & 0.82 & 0.83 & 0.82 & $<\mathrm{LOQ}$ & 0.83 & 0.84 & $<\mathrm{LOQ}-0.84$ \\
\hline $\mathrm{BaP}$ & $<\mathrm{LOQ}$ & $<\mathrm{LOQ}$ & $<\mathrm{LOQ}$ & $<$ LOQ & 0.80 & $<\mathrm{LOQ}$ & 0.79 & $<\mathrm{LOQ}$ & 0.81 & $<$ LOQ & $<\mathrm{LOQ}-0.81$ \\
\hline DahA & 0.71 & 0.69 & 0.86 & 0.71 & 0.71 & 0.71 & 0.35 & $<\mathrm{LOQ}$ & 0.71 & 0.73 & $<\mathrm{LOQ}-0.86$ \\
\hline BghiP & 0.99 & 0.99 & 0.98 & 0.99 & 0.99 & 0.99 & 0.99 & $<\mathrm{LOQ}$ & 0.99 & 1.10 & $<\mathrm{LOQ}-1.10$ \\
\hline Ipy & 0.79 & 0.39 & 0.78 & 0.78 & 0.78 & 0.79 & 0.78 & $<\mathrm{LOQ}$ & 0.79 & 0.81 & $<\mathrm{LOQ}-0.81$ \\
\hline
\end{tabular}

PAHs - polycyclic aromatic hydrocarbons, $\mathrm{Na}$ - naphthalene, LOQ - limit of quantification, Ace - acenaphtene, $\mathrm{Fl}$ - fluorene, Phe - phenanthrene, Ant - anthracene, $\mathrm{Fu}$ - fluoranthene, $\mathrm{Py}$ - pyrene, $\mathrm{BaA}$ - benzo $[a]$ anthracene, $\mathrm{Chr}$ - chrysene, $\mathrm{BbF}$ - benzo $[b]$ fluoranthene, $\mathrm{BkF}$ - benzo $[k]$-fluoranthene, BaP - benzo $[a]$ pyrene, DahA - dibenzo $[a, h]$ anthracene, BghiP - benzo[g,h,i]perylene, Ipy - indeno[ $1,2,3-c, d]$ pyrene

Table 3. Concentrations of polycyclic aromatic hydrocarbons $\left(\mu \mathrm{g}^{\mathrm{kg}}{ }^{-1}\right)$ in honey samples collected from retail.

\begin{tabular}{|c|c|c|c|c|c|c|c|c|c|c|c|}
\hline \multirow{2}{*}{ PAHs } & \multicolumn{10}{|c|}{ Honey samples } & \multirow{2}{*}{ Range } \\
\hline & 11 & 12 & 13 & 14 & 15 & 16 & 17 & 18 & 19 & 20 & \\
\hline$\overline{\mathrm{Na}}$ & $<$ LOQ & $<$ LOQ & 1.30 & $<$ LOQ & $<$ LOQ & $<$ LOQ & $<$ LOQ & $<\mathrm{LOQ}$ & $<\mathrm{LOQ}$ & $<\mathrm{LOQ}$ & $<\mathrm{LOQ}-1.30$ \\
\hline Ace & $<\mathrm{LOQ}$ & $<$ LOQ & 1.10 & 0.53 & 1.92 & $<\mathrm{LOQ}$ & 1.47 & $<\mathrm{LOQ}$ & $<\mathrm{LOQ}$ & 1.14 & $<\mathrm{LOQ}-1.47$ \\
\hline $\mathrm{Fl}$ & 0.55 & 0.62 & 0.88 & $<$ LOQ & $<\mathrm{LOQ}$ & 1.29 & 0.24 & 0.80 & 0.63 & 1.93 & $<\mathrm{LOQ}-1.93$ \\
\hline Phe & 0.68 & 1.30 & 1.50 & 0.06 & 0.31 & 1.80 & 0.85 & 0.77 & 0.92 & 0.13 & $0.06-1.50$ \\
\hline Ant & 0.73 & 0.74 & 0.05 & $<\mathrm{LOQ}$ & $<\mathrm{LOQ}$ & 0.74 & 0.04 & 0.73 & 0.73 & 0.43 & $<\mathrm{LOQ}-0.74$ \\
\hline $\mathrm{Fu}$ & $<\mathrm{LOQ}$ & $<\mathrm{LOQ}$ & $<\mathrm{LOQ}$ & $<\mathrm{LOQ}$ & $<\mathrm{LOQ}$ & $<$ LOQ & $<\mathrm{LOQ}$ & $<\mathrm{LOQ}$ & $<\mathrm{LOQ}$ & $<\mathrm{LOQ}$ & $<\mathrm{LOQ}$ \\
\hline Py & 0.54 & $<\mathrm{LOQ}$ & 0.97 & $<\mathrm{LOQ}$ & $<\mathrm{LOQ}$ & 0.58 & $<$ LOQ & 0.53 & 0.54 & $<$ LOQ & $<\mathrm{LOQ}-0.97$ \\
\hline $\mathrm{BaA}$ & 1.41 & 1.40 & 0.20 & 0.05 & 0.13 & 1.40 & 0.11 & 1.41 & 1.40 & 0.52 & $0.05-1.41$ \\
\hline Chr & 1.28 & 1.28 & 0.24 & 0.10 & 0.13 & 1.26 & 0.19 & 1.30 & 1.26 & 0.42 & $0.10-1.30$ \\
\hline $\mathrm{BbF}$ & 0.44 & 0.44 & $<\mathrm{LOQ}$ & $<\mathrm{LOQ}$ & $<\mathrm{LOQ}$ & 0.45 & $<$ LOQ & 0.91 & 0.44 & $<\mathrm{LOQ}$ & $<\mathrm{LOQ}-0.91$ \\
\hline $\mathrm{BkF}$ & 0.83 & 0.41 & 0.04 & $<\mathrm{LOQ}$ & $<\mathrm{LOQ}$ & 0.83 & 0.04 & 0.83 & 0.83 & 0.04 & $<\mathrm{LOQ}-0.83$ \\
\hline $\mathrm{BaP}$ & $<\mathrm{LOQ}$ & $<\mathrm{LOQ}$ & $<\mathrm{LOQ}$ & $<\mathrm{LOQ}$ & $<\mathrm{LOQ}$ & $<$ LOQ & $<$ LOQ & 0.83 & 0.81 & $<$ LOQ & $<\mathrm{LOQ}-0.83$ \\
\hline DahA & 0.71 & 0.36 & 0.09 & $<\mathrm{LOQ}$ & $<\mathrm{LOQ}$ & 0.71 & 0.04 & 0.71 & 0.72 & 0.10 & $<\mathrm{LOQ}-0.72$ \\
\hline BghiP & 0.99 & 0.50 & 0.10 & $<\mathrm{LOQ}$ & $<\mathrm{LOQ}$ & 0.99 & 0.11 & 0.99 & 1.00 & 0.17 & $<\mathrm{LOQ}-1.00$ \\
\hline Ipy & 0.79 & 0.39 & $<\mathrm{LOQ}$ & $<\mathrm{LOQ}$ & $<\mathrm{LOQ}$ & 0.79 & $<$ LOQ & 0.80 & 0.79 & 0.19 & $<\mathrm{LOQ}-0.80$ \\
\hline
\end{tabular}

PAHs - polycyclic aromatic hydrocarbons, $\mathrm{Na}$ - naphtalene, LOQ - limit of quantification, Ace - acenaphtene, $\mathrm{Fl}$ - fluorene, Phe - phenanthrene, Ant - anthracene, $\mathrm{Fu}$ - fluoranthene, Py - pyrene, BaA - benzo $[a]$ anthracene, $\mathrm{Chr}$ - chrysene, $\mathrm{BbF}$ - benzo[ $b]$ fluoranthene, $\mathrm{BkF}$ - benzo $[k]$-fluoranthene, $\mathrm{BaP}$ - benzo $[a]$ pyrene, DahA - dibenzo $[a, h]$ anthracene, BghiP - benzo $[g, h, i]$ perylene, Ipy - indeno $[1,2,3-c, d]$ pyrene 


\section{Risk elements}

The method AAS showed the following detection limits (defined as the concentration equivalent to three times the standard deviation of the analytical blank signal, $\mathrm{n}=10$ ) $0.25 \mu \mathrm{g} \cdot \mathrm{kg}^{-1}, 4.5 \mu \mathrm{g} \cdot \mathrm{kg}^{-1}$ and $0.9 \mu \mathrm{g} \cdot \mathrm{kg}^{-1}$ for $\mathrm{Cd}, \mathrm{Pb}$ and As, respectively. The recovery test ranged from $93.5 \%$ to $104.1 \%$ for individual elements. Detection limit for mercury was $0.01 \mathrm{ng} \cdot \mathrm{kg}^{-1}$. Concentrations of $\mathrm{Hg}, \mathrm{Cd}$, and $\mathrm{Pb}$ were found in the range of $3.24 \mu \mathrm{g}^{\mathrm{kg}} \mathrm{kg}^{-1}$ to $11.31 \mu \mathrm{g} \cdot \mathrm{kg}^{-1}, 0.95 \mu \mathrm{g} \cdot \mathrm{kg}^{-1}$ to $32.35 \mu \mathrm{g} \cdot \mathrm{kg}^{-1}$, and $22.8 \mu \mathrm{g} \cdot \mathrm{kg}^{-1}$ to $177.85 \mu \mathrm{g} \cdot \mathrm{kg}^{-1}$, respectively. Concentration of arsenic exceeded the detection limit only in three samples, ranging from $3.51 \mu \mathrm{g} \cdot \mathrm{kg}^{-1}$ to $4.35 \mu \mathrm{g} \cdot \mathrm{kg}^{-1}$ (Table 4 and 5). Table 6 presents comparisons of toxicology limits of provisional tolerable weekly intake (PTWI), and the calculated amount of honey that would meet the toxicology limit (NTL - weight of honey sample

Table 4. Concentration of trace elements $\left(\mu \mathrm{g} \cdot \mathrm{kg}^{-1}\right)$ in honey collected from beekeepers.

\begin{tabular}{|c|c|c|c|c|c|c|c|c|c|c|c|c|}
\hline \multirow[b]{2}{*}{$\begin{array}{l}\text { Trace } \\
\text { elements }\end{array}$} & \multicolumn{10}{|c|}{ Honey samples } & \multirow{2}{*}{ Range ${ }^{A c}$} & Acceptable \\
\hline & 1 & 2 & 3 & 4 & 5 & 6 & 7 & 8 & 9 & 10 & & $\begin{array}{l}\text { mits } \\
\left(\mathrm{kg}^{-1}\right)^{2}\end{array}$ \\
\hline $\mathrm{Hg}$ & 5.06 & 8.73 & 11.31 & 9.49 & 8.69 & 6.22 & 6.53 & 6.84 & 6.97 & 5.78 & $5.06-11.31$ & 20 \\
\hline $\mathrm{Cd}$ & 1.25 & 4.05 & 12.4 & 32.35 & 3.05 & 0.95 & 1.55 & 19.6 & 4.15 & 1.85 & $0.95-32.35$ & 100 \\
\hline $\mathrm{Pb}$ & 39.25 & 177.85 & 24.1 & 45.5 & 41.9 & 37.15 & 22.8 & 76 & 97.4 & 51.6 & $22.8-117.85$ & 200 \\
\hline As & $<1.00$ & 4.35 & $<1.00$ & 3.51 & $<1.00$ & $<1.00$ & $<1.00$ & $<1.00$ & $<1.00$ & $<1.00$ & $<1.00-4.35$ & 100 \\
\hline
\end{tabular}

${ }^{a}$ Acceptable limits for infant formula (Decree no. 305/2004 Coll. and Commission Regulation (EC) No. 1881/2006)

Table 5. Concentration of trace elements $\left(\mu \mathrm{g} \cdot \mathrm{kg}^{-1}\right)$ in honey collected from beekeepers and from retail.

\begin{tabular}{|c|c|c|c|c|c|c|c|c|c|c|c|c|}
\hline \multirow[b]{2}{*}{$\begin{array}{l}\text { Trace } \\
\text { elements }\end{array}$} & \multirow[b]{2}{*}{11} & \multirow[b]{2}{*}{12} & \multicolumn{8}{|c|}{ Honey samples } & \multirow{2}{*}{ Range } & Acceptable \\
\hline & & & 13 & 14 & 15 & 16 & 17 & 18 & 19 & 20 & & $\begin{array}{l}\text { imits } \\
\left.\mathrm{g} \cdot \mathrm{kg}^{-1}\right)^{\mathrm{a}}\end{array}$ \\
\hline $\mathrm{Hg}$ & 7.23 & 5.97 & 5.95 & 3.24 & 4.44 & 4.99 & 4.49 & 5.18 & 4.29 & 3.78 & $3.24-7.23$ & 20 \\
\hline $\mathrm{Cd}$ & 5.8 & 1.65 & 1.5 & 21.65 & 21.65 & 3.9 & 2.25 & 1.35 & 4.15 & 7.55 & $1.35-21.65$ & 100 \\
\hline $\mathrm{Pb}$ & 69.75 & 31.55 & 31.05 & 37.05 & 78.4 & 78.9 & 53.8 & 46.55 & 94 & 34.75 & $31.05-94.00$ & 200 \\
\hline As & 3.65 & $<1.00$ & $<1.00$ & $<1.00$ & $<1.00$ & $<1.00$ & $<1.00$ & $<1.00$ & $<1.00$ & $<1.00$ & $<1.00-3.65$ & 100 \\
\hline
\end{tabular}

${ }^{a}$ Acceptable limits for infant formula (Decree no. 305/2004 Coll. and Commission Regulation (EC) No. 1881/2006)

Table 6. Comparison of maximum concentration of pollutants in honey with toxicology limits of the World Health Organization.

\begin{tabular}{|c|c|c|c|c|c|}
\hline & PTWI (WHO) & Honey & $\mathrm{c}\left(\mu \mathrm{g} \cdot \mathrm{kg}^{-1}\right)$ & $\mathrm{D}(\mu \mathrm{g})$ & NTL $(\mathrm{kg})$ \\
\hline \multirow{2}{*}{$\mathrm{Hg}$} & \multirow{2}{*}{$4 \mu \mathrm{g} \cdot \mathrm{kg}^{-1}$ bw per week ${ }^{\mathrm{a}}$} & beekeepers & 11.31 & \multirow{2}{*}{280} & 24.76 \\
\hline & & retail & 7.23 & & 38.72 \\
\hline \multirow{2}{*}{ As } & \multirow{2}{*}{$15 \mu \mathrm{g} \cdot \mathrm{kg}^{-1}$ bw per week ${ }^{\mathrm{b}}$} & beekeepers & 4.35 & \multirow{2}{*}{1050} & 241.4 \\
\hline & & retail & 3.65 & & 287.7 \\
\hline \multirow{2}{*}{$\mathrm{Pb}$} & \multirow{2}{*}{$25 \mu \mathrm{g} \cdot \mathrm{kg}^{-1}$ bw per week } & beekeepers & 177.85 & \multirow{2}{*}{1750} & 9.84 \\
\hline & & retail & 94.00 & & 18.61 \\
\hline \multirow{2}{*}{$\mathrm{Cd}$} & \multirow{2}{*}{$7 \mu \mathrm{g} \cdot \mathrm{kg}^{-1}$ bw per week } & beekeepers & 32.35 & \multirow{2}{*}{490} & 15.15 \\
\hline & & retail & 21.65 & & 22.63 \\
\hline
\end{tabular}

PTWI - provisional tolerable weekly intake (JECFA/72/SC 2010), WHO - World Health Organization, bw - body weight, $\mathrm{c}$ - maximum concentration, $\mathrm{D}$ - tolerable weekly amount of pollutant expressed in micrograms per person; $\mathrm{D}=\mathrm{PTWI} \times \mathrm{W}$, $\mathrm{W}$ - average personal weight $(70 \mathrm{~kg})$, NTL - weight of honey sample for filling toxicology limits expressed in kilograms per week; NTL $=\mathrm{D} / \mathrm{c},{ }^{\mathrm{a}}-$ value for inorganic $\mathrm{Hg}$ (other than fish and shellfish), ${ }^{\mathrm{b}}-$ value for inorganic As 
for meeting toxicology limits). Calculation was carried out for maximal concentration of target analytes in honey.

\section{Discussion}

There were no significant differences of PAH and trace element contents between honey samples collected form beekeepers and from Brno retail stores, and between blossom and honey dew honey.

The results of polycyclic aromatic hydrocarbon content in honey obtained in our study correspond with data published by Perugini et al. (2009) from Italy and are lower than $\mathrm{PAH}$ values in honey from Romania (Dobrinas et al. 2008). Maximum residue levels (MRLs) for PAHs in honey are not set. The Commission Regulation only sets limits of $\mathrm{BaP}$ for oils, fats, smoked meats, smoked fish and sea food, processed cereal-based food, baby food, infant's formula and milk and dietary foods for special medical purposes intended specifically for infants. Our results may be compared with limits for BaP in uncontaminated food matrix, e.g. infant formula $\left(1.0 \mu \mathrm{g} \cdot \mathrm{kg}^{-1}\right)$ (Commission Regulation (EC) No 1881/2006). This limit was not exceeded in any of the samples.

The values of risk elements could be compared with maximum levels of heavy metals in children's food. The maximum level limits for mercury, cadmium, and arsenic in children's and infant's food is $20 \mu \mathrm{g} \cdot \mathrm{kg}^{-1}, 100 \mu \mathrm{g} \cdot \mathrm{kg}^{-1}$, and $100 \mu \mathrm{g} \cdot \mathrm{kg}^{-1}$, respectively (Decree no. 305/2004 Coll.), for lead $20 \mu \mathrm{g} \cdot \mathrm{kg}^{-1}$ (Commission Regulation (EC) No 1881/2006). Lead fills toxicology limits. The value of lead in honey in our study are similar to results from Lithuania (Juodisius and Simoneliene 2009). Higher concentration of lead and cadmium were detected in Turkey (Leblebici and Aksoy 2008). Concentration of cadmium in our samples was higher than in the samples from Lithuania (Juodisius and Simoneliene 2009), Italy (Pisany et al. 2008), and Canary Islands (Trias et al. 2008). The samples analyzed in our study were collected from an urban area, so possible sources of contamination include anthropogenic activity, industry or traffic. The concentrations of mercury and arsenic in our samples were very low compared to the concentrations in honey from other European countries (Pisany et al. 2008) and correspond to the amount of these elements in honey from an area with no industrial load (Toporčák et al. 1992). The concentration of trace elements did not exceed acceptable limits for infant's food. In reference to these results of trace elements analysis and the average consumption portion of honey $(20 \mathrm{~g})$ we can conclude that the daily intake of honey poses a very low hygienic risk for consumers.

In conclusion, our results confirm that Czech honey from the South Moravian region of the Czech Republic may be considered safe food of high quality indicating good hygiene of manufacturing and bee keeping practices.

\section{Acknowledgments}

The study was supported by project MSM 6215712402 "Veterinary Aspects of Food Safety and Quality" of the Ministry of Education Youth and Sports of the Czech Republic.

\section{References}

Alexander J, Benford D, Cockburn A, Cravedi J, Dogliotti E, Di Domenico A, Fernández-Cruz M, L, FinkGremmels J, Fürst P, Galli C, Grandjean P, Azyl J, Heinemeyer G, Johansson N, Mutti A, Schlatter J, Van Leeuwen R, Van Peteghem C, Verger P 2008: Scientific opinion of the panel on contaminants in the food chain on a request from the European Commission on polycyclic aromatic hydrocarbons in food 2008. EFSA J 724: $1-114$

Blasco C, Fernández M, Pena A, Lino C, Silveira MI, Font G, Picó Y 2003: Assessment of pesticide residues in honey samples from Portugal and Spain. J Agr Food Chem 51: 8132-8138

Bogdanov S, Haldimann M, Luginbuhl W, Gallmann P 2007: Minerals in honey: Environmental, geographical and botanical aspects. J Apicult Res 46: 269-275 
Claudianos C, Ranson H, Johnson, RM, Biswas S, Schuler MA, Berenbaum MR, Feyereisen R, Oakeshott JG 2006: A deficit of detoxification enzymes: pesticide sensitivity and environmental response in the honeybee. Insect Mol Biol 15: 615-636

Conti ME, Botre F 2001: Honeybees and their product as potential bioindicators of heavy metals contamination. Environ Monit Assess 69: 267-282

Čelechovská O, Vorlová L 2001: Groups of honey - physicochemical properties and heavy metals. Acta Vet Brno 70: $91-95$

Decree No. 305/2004 Coll., determining types of contaminating and toxic substances and their admissible levels in foodstuffs. Collection of Laws, Czech Republic, 2004, no. 100, pp. 6398-6406

Dobrinas S, Birghila S, Coatu V 2008: Assessment of polycyclic aromatic hydrocarbons in honey and propolis produced from various flowering trees and plants in Romania. J Food Compos Anal 27: 71-77

EPA/630/R-98/002 1986: Guidance for health risk from exposure to chemical mixtures. Federal Register, No. 185, 51: 34014-34025

EU. Commission Regulation (EC) No 1881/2006 of 19 December 2006 setting maximum levels for certain contaminants in foodstuffs. Official Journal of the European Union, 2006, pp. 364/5-364/24

Ferreira RS, Anderlini RP, Anna OABES, Pimenta DC, Orsi RD, Barraviera B 2010: New nanostructured silica adjuvant (SBA-15) employed to produce antivenom in young sheep using crotalus durissus terrificus and apis mellifera venoms detoxified by cobalt-60 2010. J Toxicol Environ Health 73: 926-933

Fredes C, Montenegro G 2006: Heavy metals and other trace elements contents in Chilean honey. Cienc Investig Agrar 33: 50-58

Hammel YA, Mohamed R, Gremaud E, LeBreton, MH, Guy PA 2008: Multi-screening approach to monitor and quantify 42 antibiotic residues in honey by liquid chromatography-tandem mass spectrometry. J Chromatogr A 1177: 58-76

JECFA/72/SC 2010: Joint FAO/WHO Expert Committee on Food Additives. Seventy-second meeting, Rome, 16 - 25 February 2010. Summary and Conclusions. Food and Agriculture Organization of the United Nations, Rome, $16 \mathrm{p}$.

Juodisius E, Simoneliene A 2009: Trace metals and pesticide residues in honey on the Lithuanian market. Vet Med Zoo 45: 27-32

Lachman J, Orsák M, Hejtmánková A, Kovářová E 2010: Evaluation of antioxidant activity and total phenolics of selected Czech honeys. Food Sci Technol-Leb 43: 52-58

Leblebici Z, Aksoy A 2008: Determination of heavy metals in honey samples from Central Anatolia using plasma optical emission spectrophotometry (ICP-OES). Pol J Environ Stud 17: 549-555

Matoušková J, Chalupa J, Cígler M, Hruška K 1992: STAT Plus - Manual, version 1.01. (in Czech). Veterinary Research Institute, Brno, $168 \mathrm{p}$

Niu GD, Johnson RM, Berenbaum MR, May R 2011: Toxicity of mycotoxins to honeybees and its amelioration by propolis. Apido 42: 79-87

Perugini M, Serafino G, Giacomelli A Medrzycki P, Sabatini AG, Persano OL, Marinelli E, Amorena M 2009 : Monitoring of polycyclic aromatic hydrocarbons in bees (Apis mellifera) and honey in urban areas and wildlife reserves. J Agr Food Chem 57: 7440-7444

Pisany A, Protano G, Riccobono F 2008: Minor and trace elements in different honey types produced in Siena County (Italy). Food Chem 107: 1553-1560

Ramesh A, Walker SA, Hood DB, Guillen MD, Schneider K, Weyand EH 2004: Bioavailability and risk assessment of orally ingested polycyclic aromatic hydrocarbons. Int J Toxicol 23: 301-333

Toporčák J, Legáth J, Kulková J 1992: Koncentrácia ortute vo vzorkách včiel a medu, pochádzajúcich $\mathrm{z}$ priemyselne exponovanej a neexponovanej oblasti (Levels of mercury in samples of bees and honey from areas with and without industrial contamination). Vet Med-Czech 37: 405-412

Trias I, Rubio C, Gonzalez-Iglesias T, Gutierrez AJ, Gonzalez-Weller D, Hardisson A 2008: Metals in fresh honeys from Tenerife Island, Spain. Bull Environ Contam Toxicol 80: 30-33

Tuzen M, Silici S, Mendil D, Soylak M 2006: Trace element levels in honeys from different regions of Turkey. Food Chem 103: $325-330$ 